\title{
RELIGION IN THE 21ST CENTURY DEBATING THE POST-SECULAR TURN
}

\author{
Wouter de Been ${ }^{*}$ and Sanne Taekema**
}

For a long time there seemed to be a broad consensus in Western democracies - at least among political theorists and legal scholars - concerning the place of religion in the public sphere and the separation of church and state. However, since the end of the last century, religion has again become a highly contentious issue. With the arrival of sizable groups of immigrants for whom religion remains an integral part of their identity - not only Muslims, but also evangelical Christians - religion is back in the public square of many modern Western democracies (a place, arguably, it never really disappeared from in the United States). This reassertion of religion, Stanley Fish observed in 2005, has 're-alerted us to the fact [...] that hundreds of millions of people in the world do not observe the distinction between the private and the public, or between belief and knowledge, and that it is no longer possible for us to regard such persons as quaintly pre-modern or as needy recipients of our saving (an ironic word) wisdom'. In the same article, Fish predicted that religion was going to be the wave of the future in academics: 'Announce a lecture or panel on 'religion in our time' and you will have to hire a larger hall'. ${ }^{\prime}$

Intrigued by this resurgence of religion - and tempted by a high attendance rate we hired a larger hall and convened a conference on 'Religion in the 21st Century' at the Erasmus School of Law, in September 2011. The focus of this conference was the question: Does the revival of religion confront us with a familiar phenomenon that we can describe and analyse in tried-and-tested categories, or has religious experience transformed into something altogether different, which demands a new approach, a new way of relating to religion? The articles collected in this special issue all originate from this gathering and all, in their own way, try to come to terms with its central theme.

The secularisation thesis, in its classic Weberian form, remains a mainstay of sociology and social theory. Modernisation, rationalisation and functional differentiation are still widely believed to lead to a retreat of religion from more and more spheres of social life, to a growing disenchantment of the world and, eventually, to the disappearance of religion. However, so far, this expectation has failed to materialise. With the exception of a number of countries in Western Europe, religion remains a potent force in modern societies around the globe. This endurance, or even resurgence, of religion, as Eduardo Mendieta and Jonathan VanAntwerpen argue in a recent volume on religion in the public sphere, has called into question a number of our central notions and myths about religion: 'Religion is neither merely private, for instance, nor purely irrational. And the public sphere is neither a realm of straightforward rational deliberation nor a smooth space of unforced assent. Yet, these understandings of both religion and public life have long been pervasive, perhaps especially in academic circles'. ${ }^{2}$

Moreover, the persistence of religion has raised questions about the notion of secularism as something that needs no argument, as a mere absence of religion with no substantive content of its own. Secularism is a position in its own right, which has developed into different forms, and is not simply a neutral response to problems of religion. ${ }^{3}$ Consequently, the secular nature of liberal democracy is losing its artless, selfevident quality. Secularism is coming under increased scrutiny. Indeed, in a number of

\footnotetext{
Assistant Professor, Department of Jurisprudence, Erasmus School of Law.

** Professor of Jurisprudence, Erasmus School of Law.

S. Fish 'One University Under God?' The Chronicle of Higher Education (2005), <http://chronicle. com/article/One-University-Under-God-/45077/> (last visited 30 May 2012).

E. Mendieta and J. VanAntwerpen (eds.), The Power of Religion in the Public Sphere (2011), at 1.

More precisely: 'Secularism takes on its own meanings, values, and associations; in no case is it simply a neutral antidote to religious conflicts': C. Calhoun, M. Juergensmeyer and J. VanAntwerpen, Rethinking Secularism (2011), at 9.
} 
recent works, even the devoutly secular theorist Jürgen Habermas has retreated from his previous secularism, and has started talking about the rise of the 'post-secular' society, that needs to adjust to the enduring presence of religion, even under conditions of continuing modernisation. Not only that, but Habermas argues that liberal democracies should not shirk from using their rich religious traditions to manage the intractable issues facing the modern world, issues that purely secular thought lacks the resources to deal with. ${ }^{4}$

This re-emergence of religion and concurrent challenge to secular orthodoxy has, in turn, revamped interest in, and support for, secularism. It is as if the new assertiveness of, and interest in, religion has elicited a critical response in academic and public debates. This interest in secularism is particularly evident in the renewed appreciation for the Enlightenment - which has become a topic discussed in newspaper columns, internet blogs and television debates, - and above all, in the growing prestige of the so-called Radical Enlightenment. Philosophers of the early Radical Enlightenment, like Baruch Spinoza and Pierre Bayle, have gained stature as representatives of the truly radical democratic and secular moment in the Enlightenment. Conversely, later Enlightenment thinkers like John Locke and David Hume have been diminished. They are now often viewed as people who sold out and who diluted the towering achievements of the early Enlightenment to accommodate the political establishment and religious tradition. With respect to the separation of church and state, this revisionist view of the Enlightenment seems to suggest that the problem today is not that liberal-democratic states are not sufficiently responsive to the demands of religious groups, but that liberal-democratic states are far too accommodating to these demands. Instead of accommodating traditional Muslims and Christians, we should embrace reason and autonomy, and stand up to religious superstition and unreasoned tradition.

If these introductory remarks provide an impression of the scene in broad brush strokes, then the first contribution by Veit Bader, "Post-Secularism" or LiberalDemocratic Constitutionalism?', provides an immediate and welcome correction to this general overview. Bader subjects broad concepts and categories like secular, religion and post-secular to critical scrutiny, and censures the lack of sensitivity to the historical contingency and complexity of the phenomena these concepts refer to. There is a whiff of what the American Legal Realists used to call anti-conceptualism in Bader's analysis. 'The old categories are imposing in their purple, but they are all too big to handle', Bader seems to sigh, like the Legal Realist Karl Llewellyn before him: 'They hold too many heterogeneous items to be reliable in use'. ${ }^{5}$ Bader suggests that we should drop these concepts and all the baggage they come with from our constitutional and legal language and replace secularism with the term 'liberal-democratic constitutionalism'.

Critique of legal and political discourse also characterises the second article by Markha Valenta, 'Pluralist Democracy or Scientistic Monocracy? Debating Ritual Slaughter'. The article deals with the recent public debates that surrounded the Dutch bill to abolish ritual slaughter. Valenta provides a critical reconstruction of the debate and raises questions about the secular, techno-scientific discourse that was employed to limit the rights of religious minorities.

The third article by Ann-Sophie Vandenberghe, 'Regulating the Relationship Between State and Religion: An Economic Approach', investigates state neutrality towards religious groups in Dutch society from an economic perspective. In a way, Vandenberghe sidesteps the thorny issues of religious neutrality and secularism, and looks at forms of Dutch state aid in terms of economic neutrality. Her conclusion is that, to a large extent, state support for religious activities already tracks patterns of economic neutrality, even though there are a number of exceptions.

The focus is broadened by the international scope of the fourth article of this special issue, 'Duties of reasonable accommodation in relation to religion and the European Court of Human Rights', by Kristin Henrard. Henrard argues that duties of reasonable accommodation should be identified by the European Court of Human Rights (ECtHR) with respect to religion, in order to realise equal opportunities and substantive equality,

J. Habermas, Zwischen Naturalismus und Religion: Philosophische Aufsätze (2009), at 119-154.

K.N. Llewellyn, ‘A Realistic Jurisprudence: The Next Step', 30 Columbia Law Review 4, at 457 (1930). 
and to level the playing field and even out barriers to full participation. Henrard argues that such duties of reasonable accommodation follow logically from the ECtHR's case law.

The final article extends the discussion about the constitutional freedom of religion and conscience to the political and legal thought of the early modern period. In 'Locke and Bayle on Religious Toleration', Marlies Galenkamp addresses the current vogue of the Radical Enlightenment. She qualifies and tempers the notion that the truly modern Radical Enlightenment was betrayed by the representatives of the later Enlightenment. Through a meticulous reconstruction of Pierre Bayle's and John Locke's ideas about religious freedom and the toleration of religious diversity, Galenkamp arrives at the conclusion that both still have a great deal to contribute to a contemporary conception of the freedom of religion, a conception that should be less absolute than current constitutional doctrine assumes. 